Branimir Kalaš $\check{1}^{1}$

Vera Mirović ${ }^{2}$

Jelena Andrašić ${ }^{3}$

University of Novi Sad, Faculty of Economics Subotica
ORIGINAL SCIENTIFIC ARTICLE

DOI: $10.5937 /$ ekonomika2101017K

Received: December, 92020.

Accepted: February, 22. 2021.

\title{
MEASURING AND ESTIMATING TAX ELASTICITY IN THE REPUBLIC OF SERBIA
}

\begin{abstract}
The paper analyzes tax elasticity in the Republic of Serbia in terms of tax revenues, personal income tax, corporate income tax, value added tax, social security contributions and excises for the period 2005-2019. Tax elasticity manifest sensitivity of tax forms to a change in the gross domestic product, where results have shown that indirect taxes have higher coefficients of elasticity compared to direct taxes. Results of empirical analysis have manifested that tax revenues are elastic to a change in gross domestic product, where 1\% increase in GDP makes to a change of tax revenues for $1.31 \%$. Also, tax elasticity is the highest at corporate income tax, while revenues from value added tax and excises are also elastic in the observed period. On the other hand, personal income tax and social security contributions are inelastic to a change in the gross domestic product in the Republic of Serbia.
\end{abstract}

Key words: taxes, revenues, elasticity, Republic of Serbia

JEL classification: H2, H20, H21

\section{МЕРЕЊЕ И ОЦЕЊИВАЊЕ ЕЛАСТИЧНОСТИ ПОРЕЗА У РЕПУБЛИЩИ СРБИЈИ}

\section{Апстракт}

Рад анализира еластичност пореза у Републици Србији у погледу пореских прихода, пореза на доходак грађана, пореза на добит правних лища, пореза на додату вредност, доприноса за сочијално осигурање и акииза за период 20052019. године. Еластичност пореза манифестује осетьивост пореских облика на промену бруто домаћег производа, где су резултати показали да индиректни порези имају веће коефииијенте еластичности у односу на директне порезе. Резултати емпиријске анализе су показали да су порески приходи еластични на промену бруто домаћег производа, где повећаюе ГДП за 1\% доводи до промене пореских прихода за 1.31\%. Такође, еластичност пореза је највећа код пореза на добит правних лииа, док су такође приходи од пореза на додату вредност и акциза еластични у посматраном периоду. С друге стране, порез на доходак

\footnotetext{
${ }^{1}$ branimir.kalas@ef.uns.ac.rs, ORCID ID 0000-0002-9141-7957

2vera.mirovic@ef.uns.ac.rs, ORCID ID 0000-0002-1465-4692

3 jelenadj@ef.uns.ac.rs, ORCID ID 0000-0003-3941-1184
} 
грађана и доприноси за сочијално осигурање су нееластични на промену бруто домаћег производа у Републичи Србији.

Кьучне речи: порези, приходи, еластичност, Република Србија

\section{Introduction}

Tax policy of an economy is one of the components of the implementation of short-term and long-term priorities determined in the economic policy that has an essential role in creating revenues (Lakatos and Karai, 2019). One of the most important issue is tax elasticity that evaluates the percentage increase in tax revenues due to changes caused by gross domestic product (Kleven, 2004). Similarly, tax elasticity tends to vary systematically over economic cycles and empirical evidences suggest that tax revenues tend to fall more strongly than their tax bases during recession, as well as, recover more strongly than their tax bases during booms (Poghosyan, 2011). Tax revenue elasticity with respect to tax base is a main parameter for the modeling of public finances (Havranek et al. 2016). It is important to estimate tax elasticity that evaluates percentage growth of tax revenue due to the changes in the base implied by a percent movement in GDP (Acharya, 2011). The structure of this research is as follows. After the introduction, there is a theoretical background about tax elasticity in the economy, as well as, analysis of tax forms in the Republic of Serbia from 2005 to $2019 \mathrm{i}$ terms of elasticity coefficients. The last segment inculdes summarizes and conclusion about tax elasticity level in the Republic of Serbia.

\section{Implications of tax elasticity}

There are many studies that have examined tax elasticity in the world (Choudry 1979; Bruce et al. 2004; Girouard and Andre, 2005; Cotton, 2012, Bunescu and Comaniciu, 2013; Belinga et al. 2014; Deli et al. 2018; Khadan 2019). Bruce et al. (2004) have investigated tax elasticity from 1967 to 2000 in the United States and results show that the elasticity for income taxes in the long-run is more than double that for sales taxes. Deli et al. (2018) have emphasized that role of tax revenue buoyancy is one of the essential issue in the consequence of the financial crisis. Belinga et al. (2014) have applied Error Correction Model for estimating tax buoyancy in thirty-four OECD countries from 1965 to 2012. Results have suggested that long-run buoyancy is not significantly different from one in about half of the observed economies. Likewise, longrun buoyancy has decreased since the late 1980, while short-run buoyancy has shown a marked increase in the same period. Tagkalakis (2015) estimated the elasticity of corporate income tax revenue to output gap in Greece from 1993 to 2013, where results have shown that elasticity is about 1.40 to 1.55 .

Kalaš et al. (2017) have revealed that personal income tax and corporate income tax are not significant for economic growth in Serbia, but value added tax has significant effect to to GDP from 2006 to 2015. Khadan (2019) has examined tax buoyancy for a twelve Caribbean countries over the period 1991-2017. Findings of this research implie 
that direct taxes have higher coefficients of elasticity compared to indirect taxes.

Tax elasticity manifests indicator that defines how strongly tax revenues response to a change of GDP (Bunescu and Comaniciu, 2013, p. 611).

$$
\text { Tax elasticity }=\frac{\Delta T R}{\Delta G D P}
$$

where: TR tax revenues, GDP - gross domestic product.

Table 1. Elasticity form

\begin{tabular}{|l|l|l|}
\hline $\mathrm{TR} / \mathrm{GDP}=\infty$ & Perfect elasticity & $\begin{array}{l}\text { A minimal change in GDP makes to a } \\
\text { maximum change in TR }\end{array}$ \\
\hline $\mathrm{TR} / \mathrm{GDP}>1$ & Elasticity & $\begin{array}{l}\text { A change in GDP makes an over } \\
\text { proportional change in TR }\end{array}$ \\
\hline $\mathrm{TR} / \mathrm{GDP}=1$ & Unitary elasticity & $\begin{array}{l}\text { A change in GDP by } 1 \% \text { makes a change } \\
\text { in TR by } 1 \%\end{array}$ \\
\hline $\mathrm{TR} / \mathrm{GDP}<1$ & Inelasticity & $\begin{array}{l}\text { A change in GDP implies a less } \\
\text { proportional change in TR }\end{array}$ \\
\hline $\mathrm{TR} / \mathrm{GDP}=0$ & Perfect inelasticity & $\begin{array}{l}\text { A maximum change in GDP does not } \\
\text { implie a change in TR }\end{array}$ \\
\hline
\end{tabular}

Source: Bunescu and Comaniciu (2013, p. 611)

Table 1. reflects four potential situations in terms of tax elasticity which depending on GDP variations. First, if tax elasticity coefficient is more than 1, TR are elastic and change in GDP manifests to an over proportional change in TR. Second, if tax elasticity coefficient is less than 1, TR are inelastic and change in GDP makes to a less proportional change in TR. Finally, if tax elasticity is $\infty$ or 0 , TR are perfect elastic or perfect inelastic. In first situation, a minimal change in GDP cause a maximum change in TR. In second situation, a maximum change in GDP does not change in TR.

Table 2. Taxes in the Republic of Serbia (mill RSD)

\begin{tabular}{|c|c|c|c|c|c|c|}
\hline Year & TR & PIT & CIT & VAT & SSC & EXC \\
\hline 2005 & 669.372 & 94.282 & 10.308 & 216.007 & 214.343 & 71.275 \\
\hline 2006 & 792.164 & 118.591 & 18.313 & 225.197 & 267.555 & 86.850 \\
\hline 2007 & 912.749 & 115.772 & 29.686 & 265.465 & 313.025 & 98.601 \\
\hline 2008 & 1.051 .717 & 136.451 & 39.007 & 301.689 & 364.081 & 110.137 \\
\hline 2009 & 1.054 .588 & 133.482 & 31.213 & 296.927 & 373.073 & 134.781 \\
\hline 2010 & 1.111 .492 & 139.051 & 32.593 & 319.369 & 378.047 & 152.167 \\
\hline 2011 & 1.191 .079 & 150.824 & 37.806 & 342.446 & 406.706 & 170.949 \\
\hline 2012 & 1.292 .564 & 165.262 & 54.779 & 367.472 & 445.566 & 181.097 \\
\hline 2013 & 1.366 .595 & 156.085 & 60.665 & 380.624 & 488.496 & 204.761 \\
\hline 2014 & 1.439 .037 & 146.484 & 72.744 & 409.564 & 509.433 & 212.473 \\
\hline 2015 & 1.463 .590 & 146.775 & 62.668 & 416.056 & 505.695 & 235.781 \\
\hline
\end{tabular}




\begin{tabular}{|l|l|l|l|l|l|l|}
\hline 2016 & 1.585 .767 & 155.065 & 80.415 & 453.503 & 527.489 & 265.606 \\
\hline 2017 & 1.717 .897 & 167.882 & 111.778 & 479.267 & 567.426 & 279.943 \\
\hline 2018 & 1.822 .236 & 179.423 & 112.488 & 499.828 & 619.666 & 290.039 \\
\hline 2019 & 1.993 .677 & 203.739 & 126.719 & 550.563 & 675.875 & 306.546 \\
\hline
\end{tabular}

Note: $\mathbf{T R}$ - tax revenues, PIT - personal income tax, CIT - corporate income tax, VAT - value added tax, SSC - social security contributions, EXC - excises.

Source: Authors based on https://www.mfin.gov.rs/en/document-type/ macroeconomic-and-fiscal-data/

Table 2. shows taxes in the Republic of Serbia from 2005 to 2019, where tax forms are expressed in million RSD. Analyzing by years, all tax forms have growth trend where TR are increased for 1.324.305 million RSD. VAT and SSC had the greatest growth above 300.000 or 400.000 million RSD, while other taxes such as PIT and CIT are increased around 110.000 million RSD in the analyzed period.

Figure 1. Average level of tax forms in the Republic of Serbia

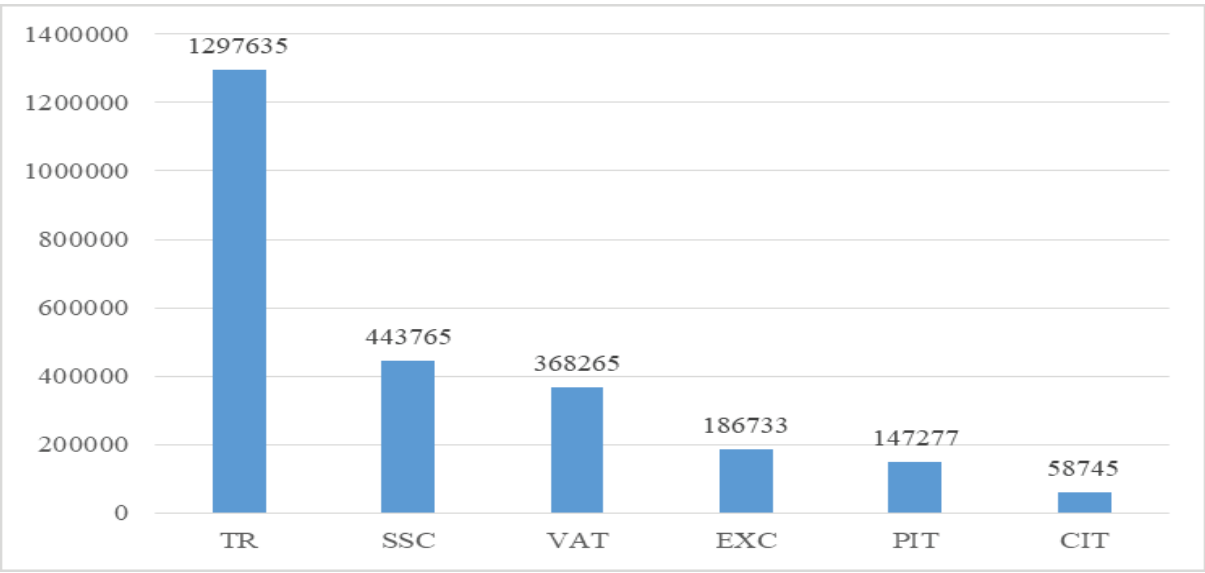

Note: TR - tax revenues, PIT - personal income tax, CIT - corporate income tax, VAT - value added tax, SSC - social security contributions, EXC - excises.

Source: Authors based on https://www.mfin.gov.rs/en/document-type/macroeconomicand-fiscal-data/

Figure 1. represents average level of tax revenues, as well as, personal income tax, corporate income tax, value added tax, social security contributions and excises from 2005 to 2019 in the Republic of Serbia. As it can see, average tax revenues are 1.297.635 million RSD, while SSC and VAT are the most generous taxes in the Republic of Serbia. Precisely, Kalaš and Milenković (2017) have determined that revenues by value added tax consist quarter of total revenues. Namely, these taxes consist more than $60 \%$ of tax revenues in the analyzed period. On the other hand, direct taxes such as PIT and CIT together have share $15.88 \%$ of tax revenues. 
Figure 2. Average growth of tax forms in the Republic of Serbia

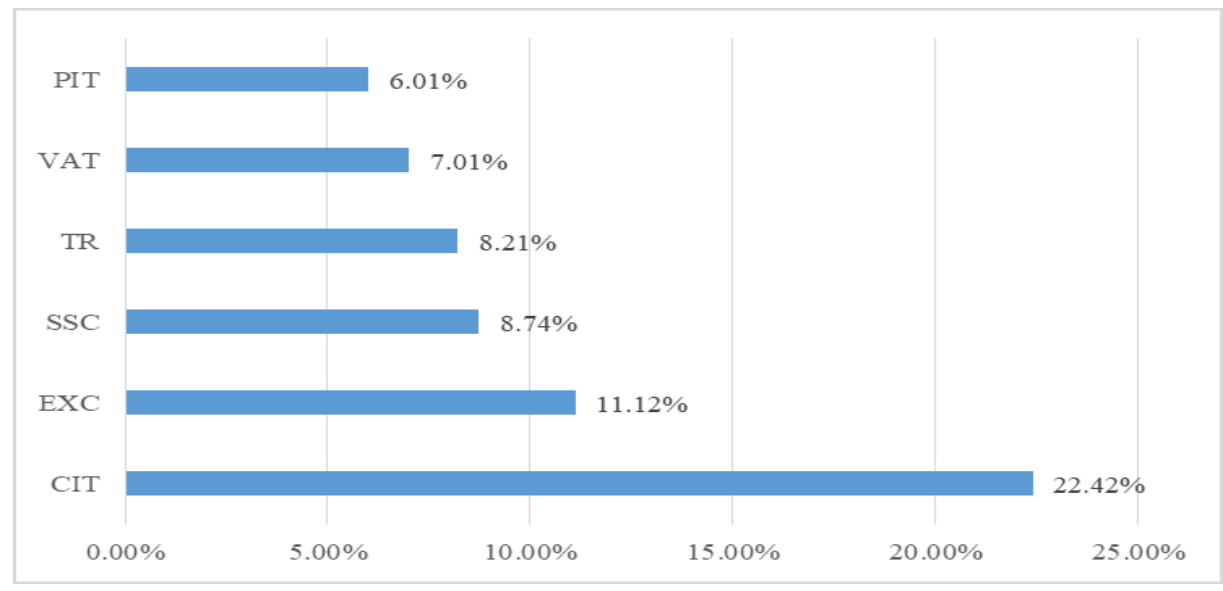

Note: TR - tax revenues, PIT - personal income tax, CIT - corporate income tax, VAT - value added tax, SSC - social security contributions, EXC - excises.

Source: Authors based on https://www.mfin.gov.rs/en/document-type/macroeconomicand-fiscal-data/

Analyzing growth rate of tax forms at average level for the period 2005-2019 in the Republic of Serbia, results have shown that corporate income tax had the greatest growth rate of $22.4 \%$. Beside corporate income tax, only excises have double growth rate of $11.12 \%$ in the observed period. The most generous tax forms such as VAT and SSC have similar growth rate of $7 \%$ or $8 \%$ compared to tax revenue growth. Finally, personal income tax had the smallest growth rate of $6.01 \%$ from 2005 to 2019 .

Table 3. Tax forms ( $\%$ in tax revenues)

\begin{tabular}{|c|c|c|c|c|c|c|}
\hline Year & PIT & CIT & VAT & SSC & EXC & TR \\
\hline 2005 & $15.55 \%$ & $1.70 \%$ & $35.63 \%$ & $35.36 \%$ & $11.76 \%$ & $100 \%$ \\
\hline 2006 & $16.55 \%$ & $2.56 \%$ & $31.43 \%$ & $37.34 \%$ & $12.12 \%$ & $100 \%$ \\
\hline 2007 & $14.07 \%$ & $3.61 \%$ & $32.27 \%$ & $38.06 \%$ & $11.99 \%$ & $100 \%$ \\
\hline 2008 & $14.34 \%$ & $4.10 \%$ & $31.71 \%$ & $38.27 \%$ & $11.58 \%$ & $100 \%$ \\
\hline 2009 & $13.77 \%$ & $3.22 \%$ & $30.63 \%$ & $38.48 \%$ & $13.90 \%$ & $100 \%$ \\
\hline 2010 & $13.62 \%$ & $3.19 \%$ & $31.27 \%$ & $37.02 \%$ & $14.90 \%$ & $100 \%$ \\
\hline 2011 & $13.60 \%$ & $3.41 \%$ & $30.89 \%$ & $36.68 \%$ & $15.42 \%$ & $100 \%$ \\
\hline 2012 & $13.61 \%$ & $4.51 \%$ & $30.27 \%$ & $36.70 \%$ & $14.92 \%$ & $100 \%$ \\
\hline 2013 & $12.09 \%$ & $4.70 \%$ & $29.49 \%$ & $37.85 \%$ & $15.87 \%$ & $100 \%$ \\
\hline 2014 & $10.85 \%$ & $5.39 \%$ & $30.32 \%$ & $37.72 \%$ & $15.73 \%$ & $100 \%$ \\
\hline 2015 & $10.74 \%$ & $4.58 \%$ & $30.44 \%$ & $36.99 \%$ & $17.25 \%$ & $100 \%$ \\
\hline 2016 & $10.46 \%$ & $5.43 \%$ & $30.60 \%$ & $35.59 \%$ & $17.92 \%$ & $100 \%$ \\
\hline
\end{tabular}




\begin{tabular}{|l|l|l|l|l|l|l|}
\hline 2017 & $10.45 \%$ & $6.96 \%$ & $29.84 \%$ & $35.33 \%$ & $17.43 \%$ & $100 \%$ \\
\hline 2018 & $10.55 \%$ & $6.61 \%$ & $29.38 \%$ & $36.42 \%$ & $17.05 \%$ & $100 \%$ \\
\hline 2019 & $10.93 \%$ & $6.80 \%$ & $29.55 \%$ & $36.27 \%$ & $16.45 \%$ & $100 \%$ \\
\hline
\end{tabular}

Note: $\mathbf{T R}$ - tax revenues, PIT - personal income tax, CIT - corporate income tax, VAT - value added tax, SSC - social security contributions, EXC - excises Source: Authors calculation

Table 3. reflects percentage share of tax forms in tax revenues by years in the Republic of Serbia. VAT and SSC have the greatest percentage share in tax revenues in every year, where their shares are above $30 \%$ of tax revenues. After them, EXC are the third generous tax in the Republic of Serbia, where it's share is increased for $4.69 \%$ from 2005 to 2019.

CIT is only tax which share is below $10 \%$, although percentage share is increased for $5.7 \%$ from 2005 to 2019 . Finally, PIT has percentage share around $10 \%$ in tax revenues, while share is smaller for $4.62 \%$ from 2005 to 2019.

Table 4. Tax elasticity in the Republic of Serbia

\begin{tabular}{|c|c|c|c|c|c|c|}
\hline Year & TR/GDP & PIT/GDP & CIT/GDP & VAT/GDP & SSC/GDP & EXC/GDP \\
\hline 2006 & 1.01 & 1.42 & 4.29 & 0.23 & 1.37 & 1.20 \\
\hline 2007 & 0.96 & -0.15 & 3.95 & 1.13 & 1.08 & 0.86 \\
\hline 2008 & 0.99 & 1.17 & 2.05 & 0.89 & 1.06 & 0.76 \\
\hline 2009 & 0.05 & -0.44 & -4.04 & -0.31 & 0.49 & 4.52 \\
\hline 2010 & 0.82 & 0.64 & 0.67 & 1.16 & 0.20 & 1.98 \\
\hline 2011 & 0.64 & 0.76 & 1.43 & 0.64 & 0.68 & 1.11 \\
\hline 2012 & 1.55 & 1.74 & 8.19 & 1.33 & 1.74 & 1.08 \\
\hline 2013 & 0.70 & -0.67 & 1.31 & 0.43 & 1.17 & 1.60 \\
\hline 2014 & 5.55 & -6.44 & 20.85 & 7.96 & 4.48 & 3.94 \\
\hline 2015 & 0.46 & 0.05 & -3.80 & 0.43 & -0.20 & 3.01 \\
\hline 2016 & 1.72 & 1.16 & 5.83 & 1.85 & 0.88 & 2.60 \\
\hline 2017 & 1.61 & 1.60 & 7.56 & 1.10 & 1.46 & 1.04 \\
\hline 2018 & 0.91 & 1.04 & 0.09 & 0.64 & 1.39 & 0.54 \\
\hline 2019 & 1.36 & 1.97 & 1.84 & 1.47 & 1.32 & 0.82 \\
\hline ATE & $\mathbf{1 . 3 1}$ & $\mathbf{0 . 2 8}$ & $\mathbf{3 . 5 9}$ & $\mathbf{1 . 3 6}$ & $\mathbf{0 . 0 1}$ & $\mathbf{1 . 2 3}$ \\
\hline
\end{tabular}

Note: TR - tax revenues, PIT - personal income tax, CIT - corporate income tax, VAT - value added tax, SSC - social security contributions, EXC - excises, GDP gross domestic product

Source: Authors calculation

Analyzing tax elasticity in the Republic of Serbia from 2005 to 2019, results manifest positive average coefficient of elasticity from aspect of all tax forms. The 
highest value of average tax elasticity is identified at CIT, while the smallest value of average taxe elasticity is recorded at SSC. It means that tax forms such as CIT, VAT and EXC are elastic to a change in GDP. Finally, personal income tax are not elastic to a change in the GDP for the period 2005-2019. Research results show that $1 \%$ increase in GDP leads to average growth of $1.31 \%$ at tax revenues, where maximum level of sensitivity is recorded in 2014 (5.55\%). Also, 1\% increase in GDP leads to growth of $3.59 \%$ at corporate income tax, $1.36 \%$ at value added tax, $1.23 \%$ and $1.23 \%$ at excises.

Table 5. Tax elasticity by type of revenues in the Republic of Serbia

\begin{tabular}{|c|c|c|c|c|c|c|c|}
\hline Year & DT & IT & \%GDP & \% DT & \% IT & $\begin{array}{l}\text { Tax } \\
\text { elasticity } \\
\text { - DT }\end{array}$ & $\begin{array}{c}\text { Tax } \\
\text { elasticity } \\
\text { - IT }\end{array}$ \\
\hline 2005 & 104.590 & 287.282 & - & - & - & - & - \\
\hline 2006 & 136.904 & 354.405 & 18.09 & 30.89 & 23.36 & 1.70 & 1.29 \\
\hline 2007 & 145.458 & 411.626 & 15.70 & 6.24 & 16.14 & 0.39 & 1.03 \\
\hline 2008 & 175.458 & 474.218 & 15.25 & 20.62 & 15.20 & 1.35 & 0.99 \\
\hline 2009 & 164.695 & 507.854 & 4.94 & -6.13 & 7.09 & -1.24 & 1.43 \\
\hline 2010 & 171.644 & 530.214 & 6.50 & 4.21 & 4.40 & 0.64 & 0.67 \\
\hline 2011 & 188.630 & 577.655 & 11.12 & 9.89 & 8.94 & 0.88 & 0.80 \\
\hline 2012 & 220.041 & 626.663 & 5.47 & 16.65 & 8.48 & 3.04 & 1.54 \\
\hline 2013 & 216.750 & 693.257 & 8.16 & -1.49 & 10.62 & -0.18 & 1.30 \\
\hline 2014 & 219.228 & 721.906 & 0.95 & 1.14 & 4.13 & 1.19 & 4.32 \\
\hline 2015 & 209.443 & 741.476 & 3.64 & -4.46 & 2.71 & -1.22 & 0.74 \\
\hline 2016 & 235.480 & 793.095 & 4.85 & 12.43 & 6.96 & 2.56 & 1.43 \\
\hline 2017 & 279.660 & 847.369 & 5.15 & 18.76 & 6.84 & 3.63 & 1.32 \\
\hline 2018 & 291.911 & 909.705 & 6.61 & 4.38 & 7.35 & 0.66 & 1.11 \\
\hline 2019 & 330.458 & 982.421 & 6.86 & 13.20 & 7.99 & 1.92 & 1.16 \\
\hline & & & $\mathbf{A T E}$ & & & $\mathbf{1 . 0 9}$ & $\mathbf{1 . 3 7}$ \\
\hline
\end{tabular}

Note: DT - direct taxes, IT - indirect taxes, GDP - gross domestic product Source: Authors calculation

If we taxes sorted in direct and indirect, results of analysis have shown that coefficient values of elasticity is higher at indirect taxes. Namely, indirect taxes are elastic (1.37) to a change in gross domestic product at average level from 2005 to 2019. On the other hand, direct taxes are unitary elastic (1.09) to a change in GDP at average level for the observed period. These results implie that indirect taxes such as VAT and EXC are more sensitive to a change in GDP compared to direct taxes such as PIT and CIT. In conditions when GDP increase for 1\%, direct taxes will rise for $1.09 \%$ at average level, while indirect taxes have greater growth by $1.37 \%$ at average level for the analzed period. 


\section{Conclusion}

The research has examined tax elasticity in the Republic of Serbia in terms of tax revenues, personal income tax, corporate income tax, value added tax, social security contributions and excises for the period 2005-2019. Empirical analysis have reflected that tax revenues are elastic to a change in gross domestic product, where $1 \%$ increase in GDP makes to a change of tax revenues for $1.31 \%$. Also, tax elasticity is the highest at corporate income tax, while revenues from value added tax and excises are also elastic in the observed period. Namely, $1 \%$ increase in GDP leads to growth of $3.59 \%$ at corporate income tax, $1.36 \%$ at value added tax, $1.23 \%$ and $1.23 \%$ at excises. On the other hand, personal income tax and social security contributions are inelastic to a change in GDP in the Republic of Serbia. Finally, results have implied that indirect taxes are more sensitive to a change in GDP compared to direct taxes. In conditions when GDP increase for $1 \%$, direct taxes will rise for $1.09 \%$ at average level, while indirect taxes have greater growth by $1.37 \%$ at average level for the analzed period.

\section{References}

Acharya, H. (2011). The Measurement of Tax Elasticity in India: A Time Series Approach. Munich Personal RePEc Archive, MPRA Paper No. 47090.

Belinga, V., Benedek, D., De Mooij, R., Norregaard., J. (2014). Tax Buoyancy in OECD Countries. International Monetary Fund Working Paper No. 110, Washington, DC.

Bruce, D., Fox. W., Tuttle, M. (2006). Tax Base Elasticities: A Multi-State Analysis of Long-Run and Short-Run Dynamics. Southern Economic Journal, 73 (2), https:// pdfs.semanticscholar.org/ed61/dcc9597c32a040b9e2cf09262b67d9240cd7.pdf

Bunescu, L., Comaniciu, C. (2013). Tax Elasticity Analysis in Romania 2001-2012. Procedia Economics and Finance, 6, 609-614.

Choudhry, N.N. (1979). Measuring the Elasticity of Tax Revenue: A Divisia Index Approach. International Monetary Fund, IMF Staff Paper, 26.

Cotton, J.J. (2012). The Buoyancy and Elasticity of Non-Oil Tax Revenues in Trinidad and Tobago (1990-2009). Central Bank of Trinidad and Tobago Working Paper.

Deli, Y., Rodriguez, A.G., Illias, K., Varthalitis, P. (2018). Dynamic tax revenue buoyancy estimates for a panel of OECD countries. The Economic and Social Research Institute, ESRI Working Paper, No. 592.

Dudine, P., Talles, J. (2017). How buoyant is the tax system? New evidence from a large heterogeneous panel. International Monetary Fund, IMF Working Paper WP/17/4, Washington, D.C.

Girouard, N., Andre, C. (2005), Measuring Cyclically-Adjusted Budget Balances for the OECD Countries, OECD Economics Department Working Papers 434.

Havranek, T., Irsova, Z., Schwarz, J. (2016). Dynamic elasticities of tax revenues: evidence from the Czech Republic. Applied Economics. 48 (60), 5866-5881. 
Kalaš, B., Milenković, I., Pjanić, M., Andrašić, J., Milenković, N. (2017). The Impact of Tax Forms on Economic Growth - Evidence from Serbia, Industry, 45(2), 113-125.

Kalaš, B., Milenković, N. (2017). The role of value added tax in the economy of Serbia. Ekonomika, 63 (2), 69-78.

Khadan, J. (2019). Tax Buoyancy in the Caribbean: Evidence from Heterogenous Panel Contegration Models. Research in Applied Economics, 11 (4), 36-48.

Kleven, H.J. (2004). Optimum taxation and the allocation of time. Journal of Public Economics, 88, 545-557.

Lakatos, M., Karai, E. (2019). After the first 32 years - new deal in Hungarian income taxation. The Annals of the Faculty of Economics in Subotica, 56 (43), 117-134.

Poghosyan, T. (2011). Assessing the Variability of Tax Elasticities in Lithuania. International Monetary Fund, IMF Working Paper No. 270, Washington, D.C.

Tagkalakis, A. (2015). Estimating the Elasticity of Corporate Income Tax to Output GAP in Greece: Implications for Tax Buoyancy. Public Finance Review 45 (2), 205-231. 